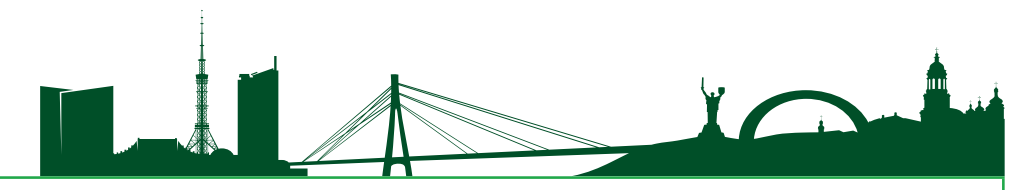

AUTHORS

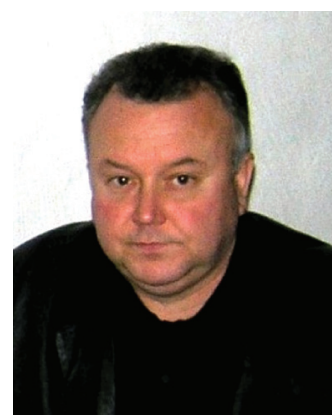

\section{SOBUTSKYI}

Associate Professor, Laboratory Manager, the National University of Water and Environmental Engineering

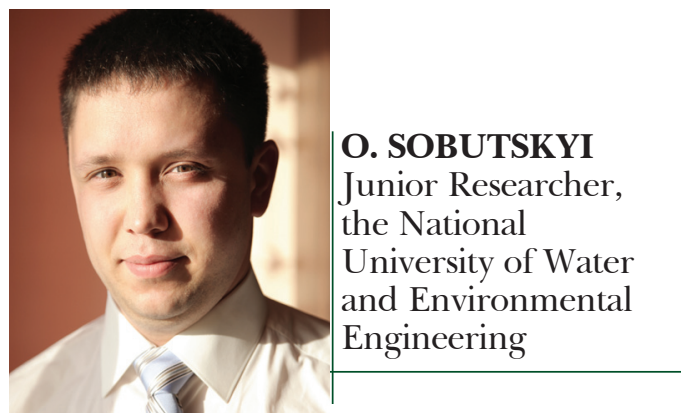

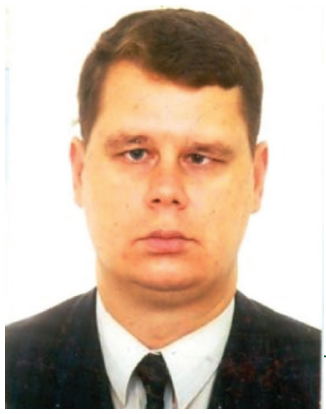

V. HUPALIUK

Associate Professor, Senior Staff Scientist, the National University of Water and Environmental Engineering

\title{
STRUCTURALLY UNSTABLE BASES. HETEROGENEITY
}

\section{ABSTRACT}

Авторами запропоновано варіант класифікацй видів структурно нестійких грунтів, шо дасть можливість унібікувати методи розрахунку їх несучої здатності.

The authors propose a version of the collapsing soils classification that will allow the unification of the methods of soils bearing capacities calculations.

\section{KEY WORDS}

soil bases, heterogeneity, non-uniform compressible bases
In the conditions of the natural occurrence the bases of buildings and constructions almost always are characterized by the considerable heterogeneity of composition and properties due to the geological conditions of formation and rheological changes of soils during their existence. The geological heterogeneity of a base is characterized by the individual layers wedging, lenticular bedding of various soils, unequal thickness of soil layers and non-uniform distribution of diverse inclusions in the soil (Table 1).

Let's consider some main examples of bases that are structurally unstable due to the hetero-geneity.

The compressed layer on a rigid sub-base. The theoretical solutions of a general character do not exist 


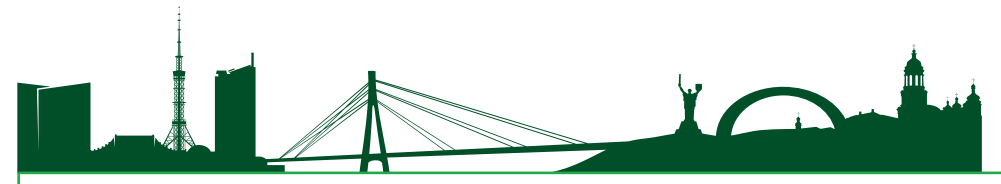

yet. Only some individual cases were studied. There are approximate methods for the examination of complex strata. The base consisting of a compressed layer underlaid by a rigid in-compressible sub-base is a very important case for practice and is theoretically studied to the fullest extent possible. The picture of stresses distribution proves to be dependent not only on the thickness and properties of a compressed upper layer, but also on the conditions at an area of contact with the sub-base. Two extreme cases have been investigated:

a) there is absolutely no friction on the contact surface;

b) the compressed layer is not able to displace relative to the rigid sub-base surface because of its considerable roughness.

The expressions obtained for the examples are rather complicated. It is worth considering some interesting consequences. If the sub-base is rigid, the stresses concentration is stronger than in a homogeneous massif. The impossibility of shears at contact areas increases the dissipation power of the compressed layer. Hence, the reverse conclusion can be made that in case when the yielding layer underlies the upper rigid layer, the stresses can be dissipated over a greater width, and the contact stress can be lower than in a homogeneous massif.

The stratum with a flexible interlayer. The thin interlayer cuts across the uniform soil column. The thin flexible interlayer usually does not introduce

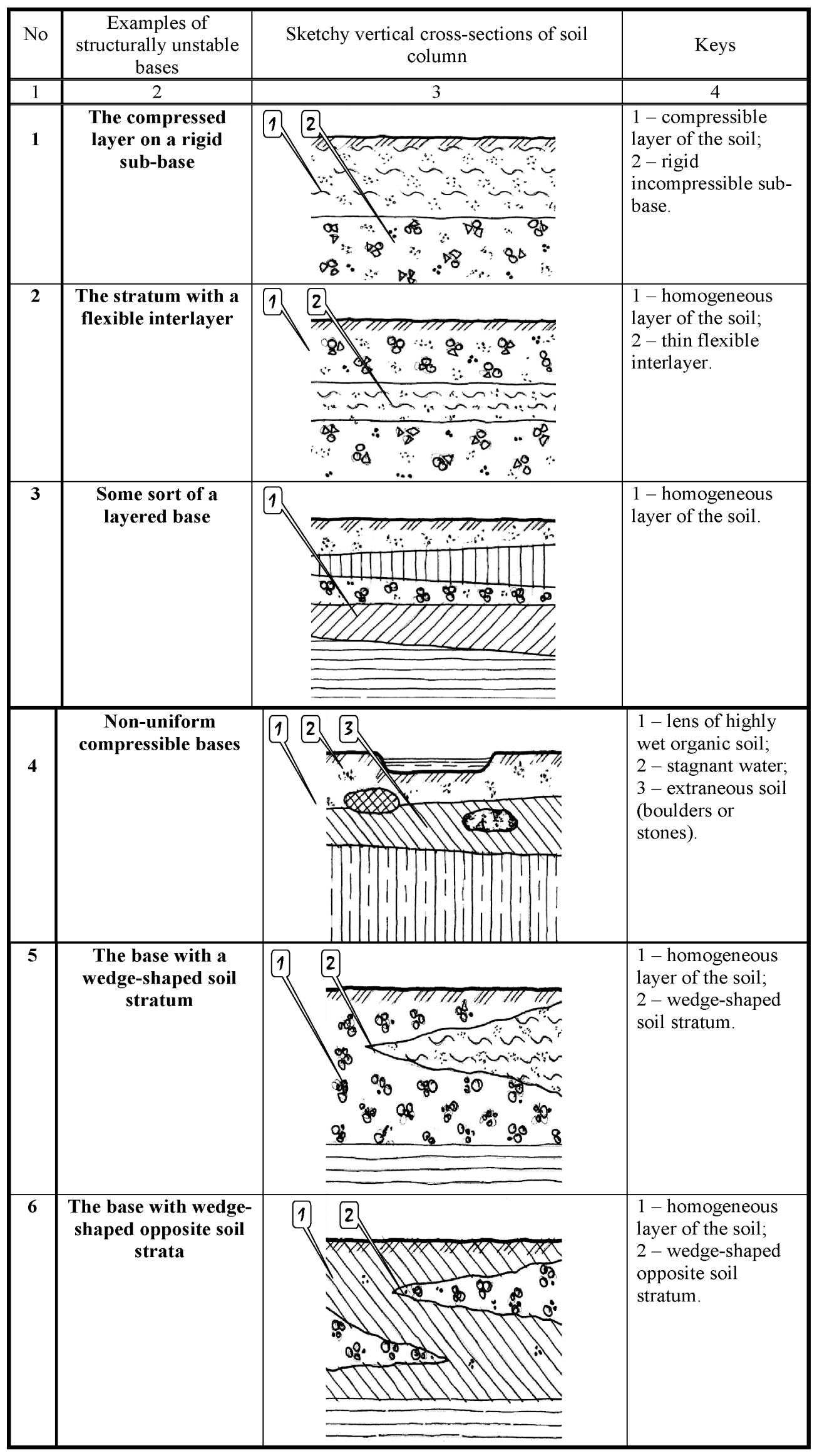




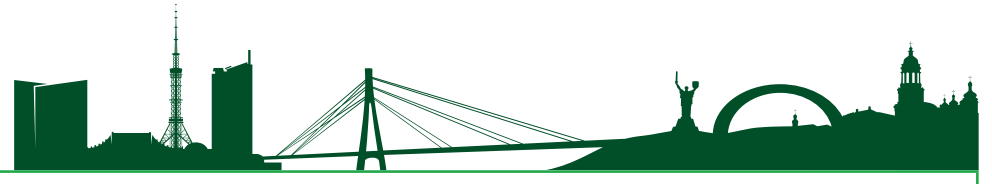

areas of glacial and postglacial periods should be explored with a special

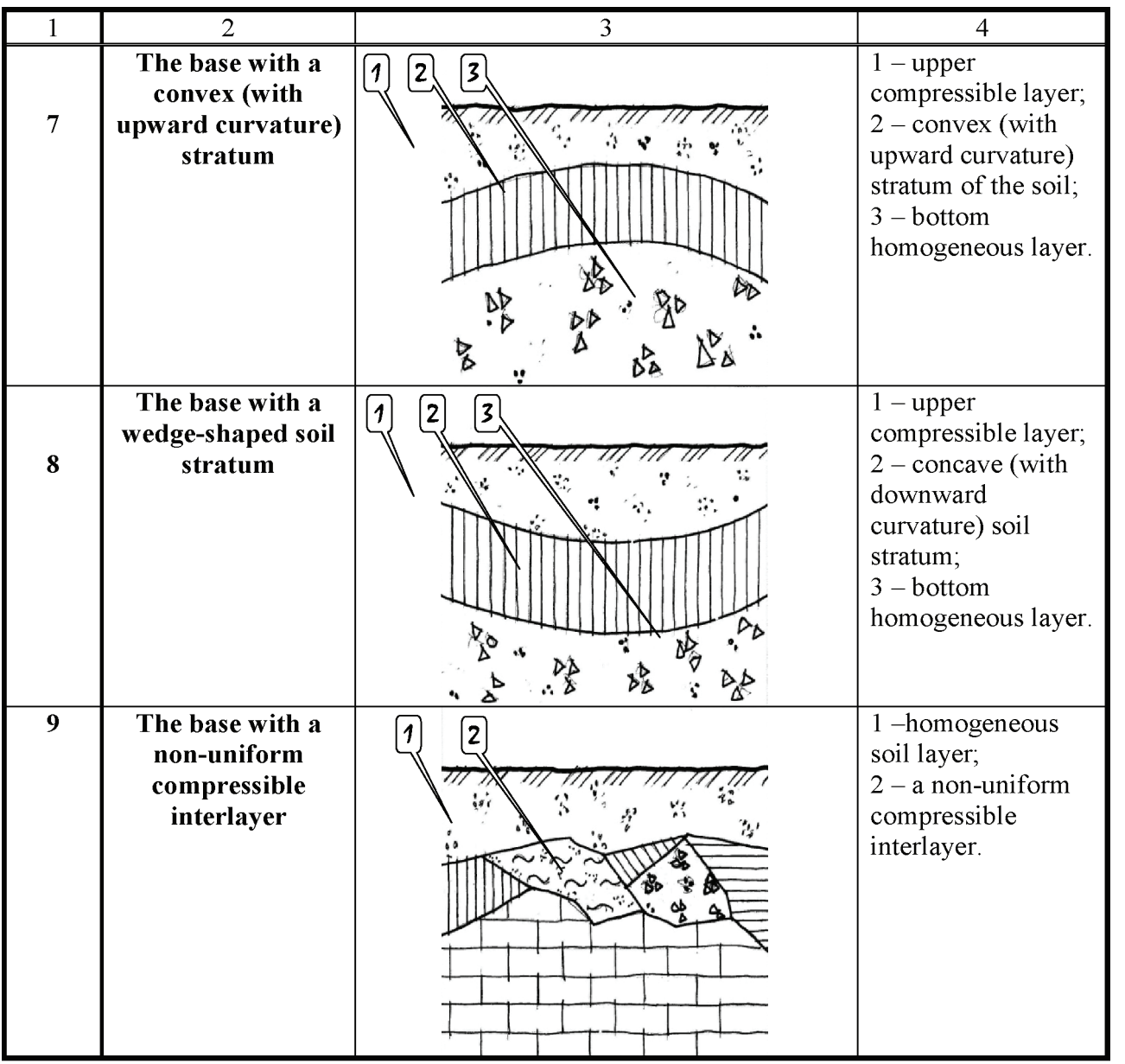
attention, as in deposits of those times the lenses of soils that are much wetter than the main soil massif may occur.

This group of anomalies can also include cases when the relatively flat areas contain the lenses of extraneous soils. The further studies showed that they were the latter fills of historical depressions in a surface or of lakes, for example, buried layers of muddy peat (Lviv city center), which per se is known as a non-uniformly compressible matter, and therefore in most cases the interlayers have very diverse thicknesses.

The non-uniform compressibility of an upper stratum may result from unsuccessful construction actions or oversights in work. The soil damages are possible

any essential changes in the stress-strain state of the whole base and its presence is almost always negligible.

Some sort of a layered base. The layered base surveys are usually executed approximately. The simplest method of the survey is an angular dissipation. The dissipation angle is taken equal to an angle of internal friction. When determining the stresses at the roof of every stratum it is necessary to take into account the dissipative action of upper strata in relation to the working load and without upper strata it should be taken as uniformly distributed constant load.

The K. Yegorov's method can be used to define the stresses for two-layered base by means of the sequential examination of two adjacent layers, or in compliance with the N. Tsytovych's method the layered base can be brought to a solid one with indirect characteristics under an assumption that the stresses are depth dissipated by a triangular stress diagram.

Non-uniformly compressible bases. The inequality of the thicknesses of soil layers composing a base is one of the causes of differential settlements. The nonuniform structure of some strata can result in the base non-uniform compressibility. In this regard the due to stagnant water, construction machinery or frost. The cases are known when the stagnant water transformed silty-clay soils at a pit bottom into stiff muddy paste for a depth of 2,0 $\mathrm{m}$ or when the excavator rhythmic rocking rarefied clay soils to a depth of $0,7 \ldots 1,0 \mathrm{~m}$.

Sometimes the non-uniform compressibility of a base can be imaginary (not real). Such nonuniformity can occur when a building (structure) is built on poor-bearing (clayey or peaty) soil during several stages (work zones). Each zone will have strains that grow by their curves.

The base with a wedge-shaped stratum of the soil. If the compressibility of deep bottom strata is lower than the compressibility of upper layers, the bottom layers influence on the overall picture of the base stress-strain state can be neglected. When the bottom layer is more compressible, it is possible to somewhat equalize the settlements by means of changing the values of the pressure on the soil. For this purpose the foundation width should be made variable, i.e. it should be the least in the zone where the compressible soil column is thinner, and the largest where the compressed soil column reaches its maximum value. However, here the problem arises with the accuracy of determining the compressibility 


\section{malla}

of base soils.

The base with a convex (curvature upwards) or concave (curvature down) stratum. If the upper layer is more compressible than the bottom one, in case of outwardly bent soil stratum the building will bulge, and in case of downwardly bent bottom stratum the building will sag. If the settlements difference will be greater than the allowable (limit) one, the different depths should be taken for foundations embedment to prevent the building damages. It can be effective enough to cut the building by means of the settlement joints into separate blocks, every of which will so obtain its individual settlement. In this case it should be taken into account that when the base bulges, the settlement joints can open at the top part of the building and its end areas can get cracks. In case of the base sag the settlement joints can close at the building top part.

The base with a non-uniform compressible interlayer. In this case the principal design provisions are the same, regardless of the interlayer disposition on the surface of the soil base or within its column. The complexity of preventing the building damage is in the fact that, as a rule, the determination of the non-uniformity degree or the non-uniform compressibility nature cannot be successfully performed. Taking into account the general relationships, for the building protection the maximum possible flexibility can be ensured to the building in order to allow its adaptation to the base deformations, or the building can be so stiffened that it could equalize by itself the base nonuniformities and therefore have an average uniform settlement.

\section{AITEPATУPA}

1. Грунти. Класифікація: ДСТУ Б В.2.1-2-96. (ГОСТ 25100-95). - [Чинний від 1997-0401]. -К.: ПНИИС НПО "Стройизыскания". - IV, 42 с. - (Національний стандарт України).

2. Клепиков С.Н. Расчет сооружений на деформируемом основании / Клепиков С.Н. К.: НИИСК, 1996. - 204 с.

3. Крутов В.И. Основания и фундаменты на просадочных грунтах / Крутов В.И. - К.: Будівельник, 1982. - 224 с.

4. УАицкий B.М. Геотехническое сопровождение реконструкции городов (обследование, расчеты, ведение работ, мониторинг) / УАицкий В.М., Шашкин А.Г. - М.: АСВ, 1999. - 327 с.

5. Левицкий Б. Неравномерные оседания основания и деформации зданий. Аркады. Варшава. - 1979., 681 с.

\section{REFERENCES}

1. Grunty. Klasyfikatsia [Soils. Classification]. (1997). DSTU B V.2.1-2-96. (GOST 2510095) from 01t April 1997. Kyiv: PNIIS NPO "Stroiizyskania" [in Ukrainian].

2. Klepikov S.N. (1996). Raschet sooruzhenii na deformiruemom osnovanii [Calculation of structures on the deformable base]. Kyiv: NIISK. - 204 p. [in Russian].

3. Krutov V.I. (1982). Osnovania i fundamenty na prosadochnych gruntakh [Foundations on subsiding soils]. Kyiv: Budivelnik. - 224 p. [in Russian].

4. Ulitskii V.M. \& Shashkin A.G. (1999). Geotechnicheskoe soprovozhdenie rekonstruktsii gorodov (obsledovanie, raschety, vedenie rabot, monitoring) [Geotechnical support for urban renewal (examination, calculations, management, monitoring)]. Moscow: ASB. - 327 p. [in Russian].

5. Levicki B. (1979). Nerownomierne osiadania podloża i odkztalcenia budynkow. [Uneven foundation settlements and building deformations]. Warszawa: Arkady. - 681 p. [in Polish]. 